DOI: http://doi.org/10.21009/JKKP.081.02

\title{
TINGKAT PENDIDIKAN DAN MOTIVASI KESIAPAN SUKSESOR PADA BISNIS KELUARGA
}

\author{
Dwi Kemala Sari $\left.{ }^{*}\right)$, Shinta Doriza ${ }^{1}$, dan Vania Zulfa ${ }^{1}$ \\ ${ }^{1}$ Program Studi Pendidikan Kesejahteraan Keluarga, Universitas Negeri Jakarta, Jakarta 13220, \\ Indonesia \\ *)E-mail: sdwikemala@gmail.com
}

\begin{abstract}
Abstrak
Bisnis keluarga merupakan bisnis yang diturunkan pendiri kepada generasi berikutnya. Tetapi tidak banyak bisnis keluarga khususnya di Indonesia yang memikirkan dan merencanakan proses suksesi. Pendidikan dan motivasi pada kesiapan suksesor merupakan bagian proses suksesi yang sangat penting dalam bisnis keluarga. Pendidikan yang tinggi diharapkan agar anak mampu mengembangkan ilmunya dalam berbagai bidang dan memenuhi keinginannya. Dalam bisnis keluarga, jika anak memiliih mengembangkan bisnis keluarga dengan ilmu yang dimiliki serta motivasi dan potensi yang ada padanya maka pendiri akan membimbingnya dengan baik. Penelitian ini bertujuan untuk mengetahui tingkat pendidikan dan motivasi kesiapan suksesor pada bisnis keluarga. Penelitian ini akan dilakukan pada generasi kedua dari pemilik usaha kuliner berasal dari budaya Betawi yang sudah menetap di DKI Jakarta. Penelitian ini menggunakan pendekatan kualitatif dan metode Interpretative Phenomenological Analysis yang pengumpulan datanya dilakukan dengan observasi, wawancara, dan dokumentasi. Hasil penelitian menunjukkan bahwa tingkat pendidikan tidak menjadi syarat khusus dalam bisnis keluarga Betawi meskipun diyakini semakin tinggi tingkat pendidikan yang dimiliki oleh suksesor dapat lebih menambah pengetahuan baik secara teori maupun praktik tentang bisnis. Selain itu awal mulanya untuk menjadi seorang suksesor tentu pendiri juga melihat dari bagaimana motivasi kesiapan suksesor yang sudah mengenal dan terlibat langsung dalam membantu pendiri mengelola bisnis keluarga.
\end{abstract}

Kata kunci: bisnis keluarga, kuliner, proses suksesi

\section{Level of Education and Motivation for Successor Readiness in Family Business}

\begin{abstract}
A family business is a business that the founders pass on to the next generation. But not many family businesses, especially in Indonesia, think about and plan the succession process. Education and motivation for successor readiness is a very important part of the succession process in a family business. High education is expected so that children can develop their knowledge in various fields and fulfill their desires. In the family business, if the child chooses to develop a family business with the knowledge they have and the motivation and potential that is in him, the founder will guide him well. This study aims to determine the level of education and motivation for successor readiness in the family business. This research will be conducted on the second generation of culinary business owners who come from Betawi culture who have settled in DKI Jakarta. This study used a qualitative approach and the Interpretative Phenomenological Analysis method, where data collection was carried out by observation, interviews, and documentation. The results show that the level of education is not a special requirement in the Betawi family business, although it is believed that the higher the level of education the successor has, the more knowledgeable both theoretically and practically about business are gained. In addition, in the beginning, to become a successor, of course the founder also saw the motivation of the readiness of successors who already know and are directly involved in helping founders manage the family business.
\end{abstract}

Keywords: culinary, family business, motivation, succession process 
Sari, Doriza, \& Zulfa, JKKP 8 (01) (2021) 11-21

\section{PENDAHULUAN}

Bisnis-bisnis entrepreneurship yang berkembang di Indonesia memberikan kontribusi yang signifikan terhadap perkembangan ekonomi negara (Soeparto, 2019). Suksesnya sebuah bisnis tentu tidak terlepas dari peran wirausaha yang tangguh. Selain memiliki berbagai ide inovatif dan kreatif, para wirusaha juga mempunyai kemampuan untuk merealisasikan berbagai gagasan dalam bentuk yang nyata. Salah satu langkah nyata yang ditempuh para wirausaha adalah dengan membuat badan usaha yang berbadan hukum. Agar para wirausaha dapat merealisasikan segala ide dan gagasan yang diinginkan, maka wirausaha harus memegang kendali atas perusahaan (Suarez, 2015). Maka jalan yang muncul adalah sebuah pendirian perusahaan keluarga. Bisnis atau perusahaan keluarga adalah sebuah perusahaan dimana terdapat kepemilikan saham yang dominan oleh suatu keluarga dan terdapat satu orang atau lebih dari anggota keluarga yang berperan aktif dalam pimpinan puncak sehingga adanya kontrol kepemilikan dan manajemen yang kuat oleh suatu keluarga dalam aktivitas perusahaan (Doriza, 2019). Munculnya bisnis keluarga menjadi daya tarik masyarakat guna meningkatkan pendapatan dan dapat mempekerjakan anggota keluarga. Anggota keluarga yang memiliki keahlian serta yang berkeinginan untuk membangun bisnis dapat bergabung mendirikan sebuah usaha, kepemilikan usaha oleh keluarga akan lebih menguntungkan karena kemudahan memperoleh modal yang dibutuhkan seperti perlengkapan dan peralatan (Afriany \& Budiarto, 2019).

Bisnis keluarga mempunyai karakteristik dan kekhasan tersendiri daripada perusahaan non keluarga. Macam karakteristik tersebut seperti kontrol atas hak suara dan arahan strategis perusahaan, prosentase kepemilikan saham, jumlah anggota keluarga yang aktif dalam manajemen, keterlibatan lebih dari satu generasi, dan lain-lain. Karakteristik perusahaan keluarga pada umumnya menganut nilai-nilai, (Atmaja, 2018) seperti: (1) diwariskan di mana perusahaan keluarga yang ideal terdiri atas keluarga-keluarga yang memahami nilai-nilai dan prinsip-prinsip dasar yang diwariskan dari pendiri atau pendahulunya. Nilai-nilai itu tercermin dalam setiap keputusan dan kegiatan bisnis; (2) Performa finansial yang kuat, perusahaan keluarga tidak hanya berpikir mengenai untung semata. Ada dua aspek finansial yang muncul dan sifat hubungan semata. Ada aspek finansial yang muncul dari sifat hubungan antar anggotanya. Karenanya sukses sebuah perusahaan keluarga bukan hanya diukur dari perolehan laba tapi juga kiprah mereka di tiga bidang: ekonomi, lingkungan hidup dan memberdayakan komunitas; (3) Membangun tata kelola yang khas, tujuan perusahaan keluarga adalah membangun bisnis yang hebat sekaligus membentuk keluarga yang tetap utuh. Dua hal ini tak mungkin terwujud kalau tidak ada tata kelola yang baik yang mengakomodasi kepentingan bisnis dan keluarga; (4) Partisipasi aktif keluarga, di mana semakin besar dan bertahan lamanya sebuah perusahaan keluarga bisa diindikasikan oleh semakin banyaknya anggota keluarga yang terlibat dan berpartisipasi secara aktif. Anggota keluarga bukan hanya menerima lembar saham dan menunggu dividen setiap tahunnya, tetapi juga bekerja keras di bidang yang menjadi tanggung jawabnya; (5) Manajemen keuangan yang konservatif, di mana banyak perusahaan yang sukses tidak agresif dalam hal investasi dengan mengandalkan pinjaman atau hutang. Mereka berhutang sedikit sekali dengan demikian senantiasa berhati-hati dalam mengembangkan bisnisnya; (6) Manajemen paradoks, banyak hal yang paradoks dalam bisnis keluarga karena kepentingan menyatukan dua kutub perusahaan dan keluarga. Misalnya saja bagaimana mengatur gaji anggota keluarga di dalam perusahaan berdasarkan pada performa kerja atau kebutuhan hidupnya, bagaimana menantang anggota keluarga untuk berkarya dengan professional; (7) Perencanaan yang selalu kontekstual dengan kepemimpinan dan kepemilikan, amat sedikit perusahaan keluarga yang punya "rencana jangka panjang" yang terlepas dari konteks siapa nanti yang akan memimpin serta siapa yang akan memiliki perusahaan. Karenanya perencanaan bisnis dan strategi tidak bisa tidak dikaitkan dengan leadership dan ownership. Dengan kata lain rencana jangka panjang yang tertulis dan harus dipatuhi tidak pernah ada atau dibuat di perusahaan keluarga. Selalu ada penyesuaian ketika suksesi melahirkan pemimpin dan pemilik baru; (8) Diversifikasi dan pertumbuhan yang dinamis, di mana bisnis 
senantiasa terkait dengan ide dan peluang di perusahaan keluarga, yang memungkinkan banyaknya pendapat atau pandangan berbagai generasi, mulai dari generasi muda hingga generasi senior. Rata-rata, perusahaan keluarga yang mendapatkan kesuksesan meski tidak dalam zona nyaman, berada dalam posisi "being", yakni kondisi melihat secara berkelanjutan mengenai produk, proses, layanan, model bisnis, promosi, distribusi, dan tata kelola; (9) Menggabungkan antara keluarga dan non keluarga, selalu ada anggota non keluarga di perusahaan keluarga. Gabungan ini di satu sisi menjadikan perusahaan keluarga semakin kuat karena kompetensi yang tidak dimiliki anggota keluarga bisa terisi oleh non anggota. Di sisi lain mereka yang bukan anggota keluarga akan cepat beradaptasi dan merasa seolaholah bagian dari keluarga tersebut. Iklim perusahaan keluarga yang ideal akan membawa semangat familiar di dalam bisnis dan menularkan kaidah serta disiplin bisnis dalam keluarga; dan (10) Suksesnya ditentukan oleh berapa lama mampu bertahan, perusahaan keluarga yang sukses mampu bertahan selama lebih dari tiga generasi. Dari kenyataan ini bahwa perusahaan tersebut bisa mengelola paradoksnya dan mengakomodir kepentingan keluarga dan perusahaan sekaligus. Tidak terpengaruh krisis ekonomi dan krisis sumber daya, semangat keluarga dan nilai-nilai perusahaan mampu membuat survive.

Pada umumnya bisnis keluarga dibangun agar dapat bertahan lama sampai ke generasi berikutnya. Untuk mencapai keberhasilan tersebut diperlukan landasan yang kuat yang dibangun oleh pendiri dan proses regenerasi yang baik pada suksesor sehingga bisnis tersebut dapat bertahan sampai lintas generasi selanjutnya. Namun mempertahankan sebuah bisnis keluarga bukan persoalan yang mudah, tentu pendiri maupun suksesor bisnis keluarga akan dihadapkan berbagai macam permasalahan yang kompleks seperti masalah pribadi, masalah hubungan keluarga, maupun masalah dalam manajemen bisnis (Kandade et al., 2020). Konflik yang berkepanjangan juga dapat berdampak pada keberlanjutan bisnis keluarga. Berdasarkan penelitian menurut Porfírio, et al. (2020) sekitar 30\% bisnis keluarga yang dapat bertahan hingga generasi kedua, kemudian sekitar $15 \%$ bisnis keluarga dapat bertahan hingga generasi ketiga dan hanya 3\% bisnis keluarga yang dapat bertahan hingga generasi keempat. Sebuah perusahaan keluarga harus memiliki komitmen yang kuat satu sama lainnya, yakni saling terlibat dalam membangun perusahaan keluarga tidak boleh salah satunya mengabaikan. Apabila diantara mereka tidak menjalankan komitmen, maka secara tidak langsung perusahaan keluarga mengarah pada kehancuran. Perusahaan keluarga yang hancur kebanyakan disebabkan oleh salah satu pihak yang menjadi dalang terjadinya kegagalan dalam keberlanjutan perusahaan keluarga tersebut. Hal ini disebut juga dengan suksesi. Suksesi adalah fenomena atas peralihan generasi pentransferan manajemen suatu perusahaan keluarga dari generasi pendiri ke generasi berikutnya (pewaris) (LeCounte 2020). Program suksesi sangat berperan penting dalam suatu keberhasilan dan keberlanjutan setiap perusahaan untuk dapat bertahan dengan para pesaing ataupun stabil (Gunawan dan Mustamu, 2015). Suksesi adalah salah satu yang fatal jika diabaikan begitu saja. Apabila ada kesalahan dalam memilih penerus atau pewaris maka akan berdampak pada keberlanjutan perusahaan keluarga kedepannya (Leonardo 2016).

Untuk menghindari kegagalan dalam membangun dan mempertahankan suatu bisnis keluarga diperlukan sebuah perencanaan suksesi dengan baik oleh pendiri. Selain itu perlunya pendidikan dan motivasi kesiapan diri dari suksesor juga mendukung dari bagian penting proses suksesi. Pendidikan dalam dunia bisnis sangat penting bertujuan untuk membekali suksesor dengan memiliki ilmu pengetahuan yang diharapkan dapat dipraktikan secara langsung dalam bisnis keluarga (Dou et al., 2020). Lembaga pendidikan merupakan salah satu faktor penting yang dapat mempengaruhi sikap seorang individu selain pengaruh orang lain, pengalaman pribadi, pengaruh kebudayaan dan media massa (Jahja 2013; Doriza, Jannah, Yulastri, Maulida, dan Patrisia, 2018). Kemudian latar belakang pendidikan orang tua memegang peranan penting dalam membentuk sikap dan tingkah laku anak serta meningkatkan sumber daya manusia yang berkualitas (Doriza et al., 2018). Maka dari itu sikap dan keputusan seorang anak sebelum memegang kendali bisnis keluarga terbentuk dari orang tua dan pendidikan yang sudah dicapainya. Dalam keluarga Betawi, selama dalam masa 
suksesi pendiri akan menentukan beberapa syarat untuk menjadi generasi penerus usaha keluarga. biasanya pendiri sudah memikirkan dan mempersiapkan suksesor sejak dini yang diawali dengan cara pendiri akan mentransferkan pengetahuan sekaligus melibatkan suksesor untuk ikutserta dalam mengelola usaha keluarga yang kemudian pendiri akan melihat motivasi dan kemampuan anaknya dalam berbisnis. Tentu untuk menjadi seorang suksesor membutuhkan waktu yang lama. Mulanya suksesor juga harus mempersiapkan diri dan meyakinkan diri agar kelak tidak salah dalam mengelola bisnis keluarga.

Dalam bisnis keluarga teori terkait hubungan keluarga dengan sikap wirausaha saling berkaitan. Berdasarkan peneltiian menurut Miroshnychenko et al. (2020) sikap suksesor untuk menjadi wirausaha dibentuk oleh keluarganya. Keinginan anak untuk memutuskan menjadi seorang suksesor tentu karena adanya sebuah motivasi dan keyakinan hal itu juga tidak terlepas dari sebuah dukungan, kepercayaan, dan bimbingan dari orang tua dengan harapan bisnis keluarga agar dapat terus bertahan dan tidak jatuh pada tangan yang salah. Selain itu tentunya menjadi seorang suksesor merupakan sebuah kesadaran anak yang memiliki minat wirausaha (Kurniawan, Khafid, dan Pujiati, 2016). Timbulnya minat berwirusaha dipengaruhi oleh faktor internal dan eksternal. Adapun faktor internal merupakan faktor yang timbul dalam diri suksesor berupa sikap atau kepribadian, motivasi, sifat-sifat personal, kemauan dan kemampuan individu yang dapat memberi kekuatan anak untuk berwirausaha. Sedangkan faktor eksternal merupakan faktor yang berasal dari luar diri anak yang memiliki minat berwirausaha yang dapat berupa unsur dari lingkungan sekitar, yaitu lingkungan keluarga, lingkungan dunia usaha, lingkungan fisik, dan lingkungan sosial ekonomi. Kewirausahaan adalah suatu disiplin ilmu yang mempelajari tentang nilai, kemampuan, dan perilaku seseorang dalam menghadapi tantangan hidup dan cara memperoleh peluang dengan berbagai resiko yang mungkin dihadapinya (Maria, 2015). Pada umumnya suksesenya sebuah bisnis keluarga bergantung pada proses suksesi yang berlangsung dari generasi ke generasi (Chan, 2019). Ada beberapa alasan alasan suksesor ingin melanjutkan usaha keluarga, beberapa diantaranya adalah tingkat motivasi pada kesiapan suksesor (Wiryakusuma, 2020). Selain itu suksesor yang memiliki motivasi dalam berkeinginan untuk melanjutkan usaha keluarga tentu akan berdampak pada kemajuan dan kesuksesan dalam suatu bisni keluarga.

Kesuksesan bisnis keluarga ini tergambar dari penjualan omzet yang masih stabil, hasil produksi yang menguntungkan, dan jumlah permintaan yang masih meningkat pada hari besar dan hari raya walaupun pada praktiknya bisnis ini telah diturunkan dari generasi sebelumnya penjagaan cita rasa, bahan baku dan metode pengelolaan tetap terjaga, nilai keluarga saling mendukung satu sama lain, saling membantu, dan adanya rasa kekeluargaan itu juga bisa menjadi kriteria agar bisnis keluarga tetap berjalan hingga sampai masa mendatang, suksesor harus memiliki nilai-nilai karakter budaya dan dapat menanamkan dalam bisnis keluarga maka dapat menjadi generasi selanjutnya dalam memimpin perusahaan. Dalam mempersiapkan suksesor, para pendiri perusahaan akan menanamkan nilai-nilai dan karakter yang menjadi salah satu syarat agar dapat menjadi penerus bisnis keluarga, yaitu memiliki karakter yang tegas, sabar, bekerja keras, serta pantang menyerah (Windarsih, 2013). Hal tersebut dapat menjadi sebuah kekuatan dalam menghadapi permasalahan di kehidupan bisnis budaya Betawi. Karakter ini juga melahirkan sifat berani menghadapi tantangan selama mereka meyakini apa yang mereka pilih itu benar.

Para pendiri perusahaan keluarga yang berasal dari budaya Betawi tersebut berdasarkan hasil observasi selalu mempersiapkan suksesor untuk meneruskan bisnis keluarga Soto Betawi H. Ma'ruf, Nasi Uduk Betawi Bang Uwan, dan Asinan Betawi Hj. Asymuni. Pada proses suksesi, mereka akan memberikan informasi sejak dini tentang nilainilai yang terdapat pada budaya Betawi tersebut agar suksesor mampu menjalankan dan menerapkan nilai-nilai khas budaya Betawi yang ada pada perusahaan keluarga mereka. Disisi lain urgensi penelitian terhadap keberhasilan bisnis ini sangat diperlukan mengingat untuk memahami budaya sebagai dasar untuk pengambilan keputusan di bisnis keluarga 
membutuhkan nilai dan peran yang besar ditengah derasnya kemajuan teknologi dan pengaruh kultur bagi generasi berikutnya (Lestari, 2018).

Rumusan masalah penelitian ini adalah bagaimana tingkat pendidikan dan motivasi kesiapan suksesor dalam bisnis keluarga? Tujuan penelitian ini adalah untuk mengetahui dan mendeskripsikan pendidikan dan motivasi kesiapan suksesor merupakan indikator penting dalam perencanaan suksesi agar bisnis keluarga dapat terus bertahan hingga lintas generasi berikutnya.

\section{METODE}

Penelitian ini menggunakan pendekatan kulitatif dengan metode Interpretative Phenomenological Analysis (IPA). IPA merupakan sebuah pendekatan penelitian kualitatif sebagaimana adanya peran peneliti sebagai instrument kunci dapat berkesempatan untuk mengeksplor dan memahami secara lebih rinci pengalaman hidup mereka. Peneliti menggunakan pendekatan kualitatif dan metode IPA karena melihat bahwa tingkat pendidikan dan motivasi kesiapan suksesor merupakan bagian penting dari sebuah proses suksesi agar bisnis keluarga dapat terus bertahan dan tidak mengalami kegagalan merupakan fenomena yang langka untuk diperbincangkan, kompleks, dinamis, penuh makna, dan patut diteliti secara mendalam berbekal informasi pemahaman informan terhadap pengalamannya.

Subjek penelitian ini adalah anak pemilik bisnis keluarga kuliner Betawi. Teknik penentuan subjek pada penelitian ini menggunakan purposive sampling. Purposive sampling merupakan sampel yang dipilih bergantung pada tujuan penelitian tanpa memperhatikan kemampuan generalisasinya (Saebani, 2017). Kriteria subjek yang ditentukan peneliti adalah generasi kedua dalam bisnis keluarga kuliner Betawi dan sudah memiliki pengalaman dalam suksesi. Teknik pengumpulan data merupakan cara yang digunakan peneliti untuk mendapatkan data dalam suatu penelitian. Teknik pengumpulan data dalam penelitian ini dilakukan dengan cara observasi, wawancara, dan dokumentasi.

Analisis data dilakukan dengan model interaktif yaitu reduksi data, penyajian data, dan penarikan kesimpulan/verifikasi sebagai sesuatu yang jalin-menjalin pada saat sebelum, selama, dan sesudah pengumpulan data dalam bentuk yang sejajar, untuk membangun wawasan umum. Validasi data dalam penelitian ini menggunakan teknik triangulasi. Triangulasi merupakan pengecekan data dari berbagai sumber dengan berbagai cara dan waktu. Penelitian ini menggunakan triangulasi sumber data dilakukan dengan membandingkan dan mengecek baik derajat kepercayaan suatu informasi yang diperoleh melalui waktu dan cara yang berbeda (Sugiyono, 2015).

\section{HASIL DAN PEMBAHASAN}

Hasil observasi pada usaha Soto Betawi menunjukan bahwa pada saat proses wawancara berlangsung situasi selama wawancara dilakukan secara online, kondisi subjek pertama dalam keadaan sedang meeting dan sikap subjek pertama sangat merespon dengan baik, ramah, dan santai ketika menjawab pertanyaan-pertanyaan yang peneliti ajukan sehingga proses wawancara dapat berjalan dengan baik. Kemudian hasil observasi pada usaha Nasi Uduk Betawi menunjukan bahwa sikap dari subjek pertama sangat baik dan ramah karena telah bersedia untuk melakukan wawancara meskipun dalam kondisi sedang melayani pembeli, proses wawancara pun berjalan dengan lancar. Selanjutnya hasil observasi pada usaha Asinan Betawi menunjukan bahwa proses wawancara berlangsung dengan baik dan lancar, subjek pertama yang menunjukan sikap apa adanya, baik, ramah, bahkan selama proses wawancara berlangsung, subjek pertama memberikan tips-tips agar sukses dalam berwirausaha. 
Hasil wawancara pada usaha Soto Betawi menunjukan bahwa pendiri usaha Soto Betawi sangat mengutamakan pendidikan terhadap anak-anaknya hal itu dibuktikan dengan subjek pertama menceritakan bahwa ketiga kakaknya telah menempuh pendidikan sarjana begitupun dengan suksesor. Bagi pendiri usaha Soto Betawi, pendidikan juga berpengaruh pada peran penerus usaha keluarga Soto Betawi agar dapat menambah wawasan dan ilmu pengetahuan. Hal ini dibuktikan dengan perkataan subjek pertama dalam wawancara yaitu:

"Dulu Bapak ngewajibin anak-anaknya kudu sekolah sampe setinggi-tingginya karna di luar aja perusahaan punya minimal pendidikan kan nah apalagi disini kita juga punya karyawan nanti kalo karyawan nanya-nanya soal bisnis, usaha, keuangan bagaimana kalo kita kurang wawasannya kan malu nantinya masa atasan kaga ngarti sih soal usaha"

Selain itu subjek pertama memperlihatkan bahwa suksesor telah menyelesaikan pendidikannya dari SMP hingga sarjana, meskipun subjek pertama mengatakan bidang yang ditempuh tidak sejalan dengan karir yang ia jalankan saat ini dan subjek pertama meyakinkan bahwa ilmu yang sudah dimiliki masih berkesinambungan dengan manajemen dalam bidang promosi di bidang usaha keluarga. Hal itu dibuktikan dalam perkataan subjek pertama yaitu:

"Saya terakhir itu S1 jurusannya Sistem Informasi ya kalo sesuai dengan karir saat ini masih bisa sedikit nyambung sih kalo dari segi pemasaran sama manajemennya tapi kalau untuk yang lain-lainnya engga saya belajar lagi kaya keuangannya jurusan saya kan ga bener-bener belajar tentang bisnis banget".

Akan tetapi, terdapat keluarga yang juga tidak mengutamakan pendidikan formal dalam meneruskan usahanya seperti subjek kedua yang hanya lulusan atau menempuh pendidikan formal hingga Sekolah Dasar (SD) walaupun adik-adiknya menempuh pendidikan hingga SMA. Walaupun begitu, subjek kedua tetap menjadi penerus usaha keluarga sehingga kewajiban menempuh pendidikan tinggi tidak diberlakukan di keluarganya. Sebagaimana hal itu dibuktikan dalam percakapan suksesor yaitu:

"Kalo saya cuma sampe SD langsung pengen nerusin usaha keluarga karna kasian orang tua gak ada yang bantu udah gitu Ade banyak akhirnya mutusin bantuin usaha Bapak aja lagian kan dasarnya teori sama praktek itu kan beda nantinya orang juga pada akhirnya kudu kerja juga cari uang meskipun ga sekolah ilmu nya kan bisa di dapat dari luar".

Lain halnya dengan subjek ketiga yang hanya menyebutkan latar belakang pendidikan yang pernah ditempuh dari SMP hingga SMA bahkan subjek ketiga pernah dua kali merasakan pendidikan sarjana diperguran tinggi namun ia mengakui hal itu tidak sampai tamat. Sebagaimana dibuktikan dengan pendapat subjek ketiga yaitu:

"Saya sampe SMA doang dulu pernah kuliah dua kali gagal dua kali gara-gara ya kuliah sambil kerja itu cape yang pertama waktu saya kerja di perusahaan pengeboran itu saya sambil kuliah manajemen tapi kelasnya malem tiap kerja saya pulang malem ya cape lumayan akhinya milih udahlah gak ngelanjutin yang kedua juga sama tapi saya ngambil jurusan yang beda pokonya cape sih kuliah sambil kerja itu".

Hal ini menunjukkan bahwa pendidikan formal dalam proses suksesi tidak diterapkan oleh seluruh keluarga Betawi. Keadaan tersebut merupakan kebijakan masing-masing keluarga. Sehingga, jawaban responden mengenai pendidikan formal memiliki jawaban beragam dalam penelitian yang dilakukan.

Kemudian hasil penelitian pada motivasi kesiapan suksesor yaitu motivasi merupakan kekuatan yang terdapat dalam diri seseorang dan mendorongnya untuk berbuat sesuatu. Dapat dikatakan juga bahwa motivasi merupakan daya pendorong yang mengakibatkan seseorang mau dan rela untuk mengerahkan kemampuan dalam bentuk keahlian atau keterampilan tenaga serta waktunya untuk menyelenggarakan berbagai kegiatan yang 
menjadi tanggung jawabnya serta menunaikan kewajibannya dalam rangka mencapai tujuan yang telah ditentukan sebelumnya (Oktiani, 2017). Dalam perusahaan keluarga, motivasi setiap individu berbeda-beda dalam membangun bisnis keluarga. Ada penerus usaha keluarga yang motivasinya menginginkan sebagai penerus usaha keluarga karena usaha tersebut dijadikan sumber penghasilan utama sementara yang lainnya sebagai sumber pendapatan sampingan, serta hanya sebagai kewajiban anak untuk menyenangkan orang tuanya (Wibisono, 2018).

Hasil penelitian menunjukkan bahwa motivasi para responden dalam penelitian beragam. Responden subjek pertama menyebutkan jika motivasinya dalam meneruskan usaha keluarga adalah ingin mengembangkan usaha tersebut dan membuka cabang lagi serta memperbaiki sistem manajemen yang sudah ada. Hal tersebut diharapkan dapat terwujud agar usaha dapat lebih maju dan sukses ketika dirinya menjalankan usaha tersebut. Hal ini dibuktikan dalam pendapat subjek pertama yaitu:

“...sekarang mah motivasinya mau usaha Soto Betawi ini terus lanjut dan bisa buka cabang lagi, manajemennya lebih baik lagi biar usaha nya lebih bagus lah dan bisa panjang umur"

Bahkan berdasarkan hasil wawancara peneliti dengan subjek kedua mengatakan bahwa motivasi yang timbul pada dirinya karena keluarga, harapan besar agar usaha keluarga Nasi Uduk Betawi dapat terus bertahan karena berawal dari usaha ini suksesor merasa bisa mencukupi kebutuhan keluarga dan bisa membiayai adik-adiknya untuk sekolah hingga tamat SMA. Sebaimana itu itu dibuktikan dengan pendapat subjek kedua yaitu:

"...saya mau bantu orang tua jualan juga karna mau ngebantuin Ade-Ade saya gamau ngerepotin orang tua, jadi mau usaha ini terus lanjut biar bisa biayain Ade-Ade sekolah sampe SMA akhirnya kesampean dan semua uangnya juga dari usaha ini juga malah sekarang Ade saya buka usaha juga dari uang usaha Nasi Uduk Betawi ini makannya harapan saya usaha ini biar terus lanjut..."

Berbeda dengan responden responden ketiga yang menyebutkan bahwa motivasi awalnya hanya untuk memenuhi permintaan orang tuanya sebagai penerus usaha keluarga namun kedepannya ia ingin usaha tersebut berjalan lebih baik lagi dan bertahan lama.Sebagaimana hal itu dibuktikan dengan pendapat subjek ketiga yaitu:

“...gaada Mbak motivasinya mah karna emang udah ditentuin sebelumnya sama bapak dulu kalo yang bakal lanjutin usaha ini harus anak pertama tapi tetep saya juga punya impian biar usaha ini terus lanjut sampe cicit malah"

Berdasarkan hasil wawancara diatas menunjukan bahwa setiap orang tentu memiliki motivasi yang berbeda-beda harapan besar dari sebuah motivasi ialah agar usaha keluarga tetap bertahan dengan pembaharuan yang sesuai dengan perkembangan zaman namun tetap tidak mengubah esensi asli budaya Betawi.

Pendidikan formal yang merupakan suatu pendidikan dengan jangka panjang dan umum serta memiliki program berupa kurikulum secara terpusat dan seragam adalah hal yang penting dalam setiap diri individu (Haerullah, 2020). Mengenai pendidikan formal yang telah disebutkan sebelumnya, di mana keluarga Betawi ada yang memberikan syarat khusus seperti menyelesaikan pendidikan formal. Pendidikan yang tinggi diharapkan agar anak mampu mengembangkan ilmunya dalam berbagai bidang dan memenuhi keinginannya. Jika anak menginginkan bekerja pada bidang lain, orang tua tidak akan melarang namun jika memilih mengembangkan bisnis keluarga dengan ilmu yang dimiliki serta potensi yang ada padanya maka keluarga akan membimbingnya dengan baik. Namun berdasarkan hasil wawancara menunjukan bahwa tingkat pendidikan suksesor berbeda-beda seperti subjek pertama yang memiliki riwayat pendidikan hingga sarjana hal itu pun didukung oleh pengakuan dari salah satu keluarga yang mengatakan pendidikan itu sangat penting dalam sebuah bisnis keluarga karena tujuan dari pendidikan adalah dapat menambah wawasan yang lebih luas. Sedangkan 
terdapat responden yang tidak menempuh pendidikan tinggi dan berhasil menjadi suksesor seperti subjek kedua. Hal tersebut diakibatkan karena pengalamannya dalam membantu usaha keluarga dan pemahamannya dalam mengelola usaha keluarga. Kemudian subjek ketiga yang menunjukan jenjang pendidikan hanya sampai Sekolah Menengah Atas (SMA) meskipun pernah menempuh pendidikan hingga sarjana tetapi subjek ketiga tetap memilih untuk lebih fokus bekerja.

Motivasi pada suksesor juga memiliki keterlibatan dalam sebuah bisnis keluarga (Wijaya, 2014). Motivasi adalah salah satunya kekuatan yang dapat membangkitkan minat seseorang kesabaran dan ketekunan untuk melakukan sesuatu (Ibrahim et al., 2004). Semakin besar motivasi suksesor maka semakin besar minat seorang suksesor untuk melanjutkan sebuah usaha keluarga. Selain itu, antara motivasi dan minat masih saling berkaitan dengan pribadi suksesor dalam perusahaan keluarga. Motivasi merupakan faktor yang menyebabkan seseorang memiliki keyakinan dan mendukung perilaku manusia, karenanya manusia bisa bekerja dengan rajin untuk mencapai tujuan mereka (Hasibuan, 2013). Berdasarkan penelitian dari Wibisono (2018) menyebutkan jika dalam perusahaan keluarga, motivasi setiap individu berbeda-beda dalam membangun bisnis keluarga. Ada penerus usaha keluarga yang motivasinya menginginkan sebagai penerus usaha keluarga karena usaha tersebut dijadikan sumber penghasilan utama sementara yang lainnya sebagai sumber pendapatan sampingan, serta hanya sebagai kewajiban anak untuk menyenangkan orang tuanya. Berdasarkan hasil wawancara dilakukan peneliti bahwa suksesor meneruskan usaha keluarga dengan berbagai motivasi. Hal tersebut diperjelas dengan jawaban responden subjek pertama bahwa motivasinya adalah ingin mengembangkan dan membuka cabang dari bisnis keluarga yang sekarang dijalaninya. Kemudian terdapat perbedaan dengan motivasi yang dimiliki oleh subjek kedua yang menyatakan jika motivasinya yaitu ingin usaha ini terus bertahan karena keluarga baginya usaha Nasi Uduk Betawi ini merupakan aset yang dapat memenuhi kebutuhan keluarga dan membiayai pendidikan Adik-Adiknya jawaban dari subjek kedua pun juga didukung oleh salah satu Adiknya yang mengungkapkan bahwa apapun yang menjadi motivasi subjek selalu diberikan dukungan oleh keluarga. Namun, responden lain subjek ketiga mengatakan jika dirinya tidak memiliki motivasi apapun kecuali hanya untuk memenuhi permintaan orang tua. Artinya, jawaban para responden memiliki keragaman hanya saja, jika motivasinya untuk memenuhi permintaan orang tua semata sebaiknya ditambahkan lagi agar usaha atau bisnis terbut bukan saja hanya 'bertahan' namun mampu berkembang agar menjangkau konsumen yang lebih luas lagi.

\section{SIMPULAN DAN SARAN}

Persiapan dan proses transisi suksesi yang terdapat pada subjek penelitian telah dilaksanakan dengan adanya keterlibatan pendiri, keluarga dan suksesor dengan cara memperkenalkan dan mengajak secara langsung suksesor ke dalam kegiatan perusahaan keluarga. Meskipun pendiri sudah melakukan persiapan namun semua akan kembali pada motivasi kesiapan diri suksesor, berdasarkan hasil penelitian ditemukan bahwa masingmasing responden sudah memiliki persiapan diri namun ada pula persiapan diri untuk menjadi generasi penerus usaha keluarga timbul ketika pendiri sudah memberikan jabatannya kepada suksesor. Pendiri bisnis keluarga Betawi dalam mempersiapkan suksesor untuk menjadi generasi penerus bisnis keluarga dilakukan secara terbuka dan bebas tergantung dari bagaimana keinginan seorang anak dan pendiri akan melihat sejauh mana kemampuan dan motivasi yang dimiliki suksesor dalam berbisnis. Pengenalan dan pembiasaan dalam berwirausaha sejak dini yang dilakukan pendiri terhadap suksesor tentu berdampak pada kinerja suksesor ketika memegang kendali atas bisnis keluarga. Selain itu pendidikan dan hubungan keluarga dapat menimbulkan motivasi kesiapan suksesor lebih matang lagi sehingga dapat menambah rasa kepercayaan dan keyakinan diri pada suksesor dalam mempimpin sebuah bisnis keluarga. 
Pada dasarnya persiapan dan proses suksesi yang dilakukan pada masing-masing perusahaan keluarga budaya Betawi berbeda-beda tergantung dari aturan, nilai dan tradisi yang berlaku pada setiap keluarga. Mampu bertahannya dari usaha rumah makan Soto Betawi H. Ma'ruf, Nasi Uduk Betawi Bang Uwan, dan Asinan Betawi Hj. Asymuni karena masingmasing pendiri telah melakukan persiapan secara matang dimulai dari mempersiapkan suksesor, kemudian suksesor telah memiliki syarat dan kriteria untuk menjadi generasi penerus usaha keluarga, mengembangkan bakat dan potensi suksesor dalam berbisnis, hingga pendiri masih memberikan bimbingan dan arahan kepada suksesor dari awal sebelum menjadi pemimpin dalam perusahaan keluarga hingga dapat mengambil alih perusahaan keluarga. Semua itu telah dilakukan bertujuan agar perusahaan dapat terus bertahan sampai saat ini dengan tetap mempertahankan nilai, tradisi, ciri khas dan citra rasa budaya Betawi sehingga konsumen tetap dapat merasakan kearifan budaya Betawi di era modern.

Pendiri maupun suksesor dapat memikirkan suksesi secara matang untuk generasigenerasi berikutnya agar bisnis keluarga dapat terus bertahan dengan ciri dan cita rasa yang khas budaya Betawi karena semakin banyaknya jenis pekerjaan yang memungkinkan penghasilan lebih besar membuat keinginan seorang anak yang seharusnya menjadi generasi penerus usaha keluarga lebih memilih bekerja diperusahaan besar. Selain itu banyaknya persaingan dalam dunia kuliner, suksesor harus bisa lebih memikirkan agar perusahaan dapat terus berkembang tanpa mengubah esensi budaya Betawi agar dapat melestarikan nuansa kuliner Betawi. Kemudian agar bisnis keluarga dapat terus bertahan pendiri perlu menentukan syarat kepada suksesor agar mengikuti pendidikan formal hingga tamat hal ini bertujuan agar suksesor dapat memiliki pengetahuan berbisnis baik secara teori maupun praktik. Selain itu, pentingnya sebuah dukungan dan komunikasi yang baik dalam hubungan keluarga guna memberikan motivasi kepada suksesor sehingga suksesor memiliki kesiapan jauh lebih matang dalam memutuskan untuk melanjutkan bisnis keluarga Betawi.

\section{DAFTAR PUSTAKA}

Afriany, N. A., Budiarto, S. D., \& Putri, A. N. (2019). Hubungan antara Kepemilikan Keluarga dengan Kesuksesan Bisnis pada Usaha Kecil \& Menengah (UKM). Jurnal Akuntansi Dewantara. 31, 67-74. https://doi.org/10.29230/ad.v3i1.4045.

Atmaja, E. H. (2018). Suksesi Kepemimpinan Perusahaan di Indonesia. Jurnal Riset Ekonomi Manajemen. 1, 45-56. https://doi.org/10.31002/rn.v1i2.712.

Budiarti, N. E. (2015). Suksesi Dan Kinerja Keuangan Atas Keberlangsungan Perusahaan Keluarga Di Indonesia. Jurnal Akuntansi AKUNESA. 1-22.

Chan, C.H. (2019). Manajemen Konflik Dalam Perencanaan Suksesi Pada Perusahaan Keluarga PT Mitra Indah Lestari. Jurnal Agora, 7, 1-6.

Cindy, W. T. (2014). Faktor-Faktor Motivasional Yang Mengklasifikasi Keterlibatan Mahasiswa Dalam Mengambil Peran Pada Bisnis Keluarganya. Jurnal Agora. 2(2), 1-6.

Doriza. (2019). Ekonomi Keluarga 2: Keluarga Yang Seimbang Dan Sejahtera. UNJ Press.

Doriza, S., Jannah, W., Yulastri, L., Maulida, E., \& Patrisia, D. (2018). Hubungan Pendidikan Orang Tua Dengan Sikap Wirausaha Mahasiswa. JKKP (Jurnal Kesejahteraan Keluarga Dan Pendidikan). 5,147-53. doi: 10.21009/JKKP.052.06.

Dou, J., Su E., Li, S., \& Holt, D. T. (2020). Transgenerational Entrepreneurship in Entrepreneurial Families: What Is Explicitly Learned and What Is Successfully Transferred?. Entrepreneurship and Regional Development Journal. doi: 10.1080/08985626.2020.1727090. 
Gunawan, D. J., \& Mustamu, H. R. (2015). Studi Deskriptif Kriteria Pemilihan Suksesor dan Proses Mentoring pada Perusahaan Air Minum dalam Kemasan. Jurnal Agora. 3:237244.

Haerullah, H. (2020). Dimensi Perkembangan Pendidikan Formal dan Non Formal. Jurnal Edukasi Nonformal, 2, 190-207.

Hasibuan, MSP. (2013). Manajemen Sumber Daya Manusia. Jakarta: PT Bumi Aksara. 120.

Ibrahim, A. B., Soufani, K., Poutziouris, P., \& Lam, J. (2004). Qualities of an Effective Successor: The Role of Education and Training." Education Training. 46, 474-80. doi: 10.1108/00400910410569597.

Jahja, Y. (2013). Psikologi Perkembangan. Djakarta Padang Bukitinggi. Ke-1, Cet. Kencana Prenada Media Group. http://library.fip.uny.ac.id/opac/index.php?p=show_detail\&id=7403\%0D.

Kandade, K., Samara, G., Parada, J. M., \& Dawson. (2020). From Family Successors to Successful Business Leaders: A Qualitative Study of How High-Quality Relationships Develop in Family Businesses. Journal of Family Business Strategy, 1-15. doi: 10.1016/j.jfbs.2019.100334.

Kurniawan, A., Khafid, M., \& Pujiati, M. (2016). Pengaruh Lingkungan Keluarga, Motivasi, Dan Kepribadian Terhadap Minat Wirausaha Melalui Self Efficacy. Journal of Economic Education. 5, 1-10. http://journal.unnes.ac.id/sju/index.php/jeec.

LeCounte, J. F. (2020). Founder-CEOs: Succession planning for the success, growth, and legacy of family firms. Journal of Small Business Management. 2-18. doi: 10.1080/00472778.2020.1725814.

Leonardo, Y. (2016). Analisis Perencanaan Suksesi pada Perusahaan Keluarga PD Bintang di Situbond. Jurnal Agora. 4, 120-128.

Lestari, D. W. (2018). Studi Fenomenologi: Memaknai Tata Kelola Perusahaan pada Bisnis Keluarga Beretnis Tionghoa di Indonesia. Jurnal Akuntansi. 2, 307-311.

Miroshnychenko, I., De Massis, A., Miller, D., \& Barontini, R. (2020). Family Business Growth Around the World. Entrepreneurship: Theory and Practice. 1-27. https://doi.org/10.1177/1042258720913028.

Oktiani, I. (2017). Kreativitas Guru dalam Memotivasi Belajar Peserta Didik. Jurnal Kependidikan. 5, 216-232. doi: 10.24090/jk.v5i2.1939.

Porfírio, J. A., Felício, J. A., \& Carrilho, T. (2020). Family business succession: Analysis of the drivers of success based on entrepreneurship theory. Journal of Business Research, 115, 250-257. doi: 10.1016/j.jbusres.2019.11.054.

Saebani, B. (2017). Buku, Pedoman Aplikatif Metode Penelitian dalam Penyusunan Skripsi, Tesis, dan Disertasi. Bandung: Pustaka Setia.

Soeparto \& Henky, S. (2019). Pencapaian Kinerja Perusahaan Keluarga Melalui Tingkat Kesiapan Suksesor Dan Hubungan Antar Anggota Keluarga Dan Bisnis. Accounting and Management Journal, 3 (2), 95-104. doi: 10.33086/amj.v3i2.1412.

Sugiyono. (2015). Metode Penelitian Kuantitatif, Kualitatif, dan R\&D. Bandung: Alfabeta.

Ulfah, M. (2015). Pendapatan Usaha, Pendidikan, Kewirausahaan, dan Lingkungan Keluarga Terhadap Minat Meneruskan Usaha Keluarga. Jurnal Riset Entrepreneurship. 1(2), 1318. doi:10.30587/jre.v1i2.408

Wibisono, U. S. (2018). Anteseden Keberlanjutan Bisnis Keluarga di Kampung Batik Laweyan dan Kauman Surakarta. Jurnal Lentera Bisnis, 7, 26-39. 
Sari, Doriza, \& Zulfa, JKKP 8 (01) (2021) 11-21

Windarsih, A. (2013). Memahami "Betawi" dalam Konteks Cagar Budaya Condet dan Setu Babakan. Jurnal Masyarakat Dan Budaya, 15, 177-200.

Wiryakusuma \& Yosia, B. G. (2020). The Motivation and Readiness of Instrumentation in Cultivating Interest of Family Business Successor. Jurnal Entrepreneur dan Entrepreneurship 9 (1), 23-28. doi: 10.37715/jee.v9i1.1238. 